\title{
Modeling and Forecasting the US Dollar/Euro Exchange Rate
}

\author{
Latife Ghalayini ${ }^{1}$ \\ ${ }^{1}$ Faculty of Economics and Business Administration, Department of Economics, Lebanese University, Lebanon \\ Correspondence: Latife Ghalayini, Faculty of Economics and Business Administration, Department of \\ economics, Lebanese University, Branch 1, El Hadath Beirut, Lebanon. Tel: 961-3-627-319. E-mail: \\ lghalayini@hotmail.com
}

Received: September 2, 2013

Accepted: October 29, $2013 \quad$ Online Published: December 23, 2013

doi:10.5539/ijef.v6n1p194

URL: http://dx.doi.org/10.5539/ijef.v6n1p194

\begin{abstract}
In theory, a currency's value should gravitate over time in the direction of its real long-run equilibrium value. The intent of this paper is to investigate the sustainability of basic exchange rate theory and to construct econometric models capable to generate consistent and rational forecasts for the dollar/euro exchange rate. Considering past values of dollar/euro exchange rate, we build first an ARIMA model and we study the volatility of this exchange rate time series. However, since macroeconomics variables influence the exchange rate, we construct a model for dollar/euro exchange rate determination including macroeconomic variables whose choices have been theoretically driven. The most important outcomes of this research are the specifications of an economic model for dollar/euro exchange rate as well the estimation of the model in The Vector Error Correction Model form.
\end{abstract}

Keywords: exchange rate, interest rate parity, power purchasing parity, business cycle, monetary aggregate

\section{Introduction}

Since the Euro takes the place of the ECU as an accounting unit beginning 1999, the large fluctuations in the dollar/euro exchange rate (in terms of dollar per euro) request more explanation of the underlying interactions. Equilibrium exchange rate modeling is not purely an arcane academic exercise. From policy perspectives, it is significant to know if the exchange rate tends to its long term equilibrium level or going away from this level. If we were able to estimate this exchange rate, investors would be able to identify the likely path that an exchange rate will take on a long-term basis and position their portfolios accordingly. Furthermore, forecasting exchange rates is very important for market participants. However, the complexity of this forecasting is proved by the fact that only three out of every ten spot foreign exchange dealers make a profit in any given year. This proves also that the foreign exchange market is efficient (Carney \& Cunningham, 1996).

In theory, a currency's value should gravitate over time in the direction of its real long-run equilibrium value. Regrettably, what exchange rate level represents a long-run equilibrium value of a currency does not constitute unanimity among economist. No accord also concerning the method that should be used to estimate this value. For instance, the approach which establishes the long-run equilibrium between the exchange rate and the price level, the purchasing power parity (PPP), is the widest subsequent among economists and strategists but it is as well recognized to have severe limitations because other fundamental forces have impact on the long-term path of exchange rates. Sartore, Trevisan, Trova and Volo (2001); Rosenberg (2003); Brent and Schnatz (2006), affirm the breakdown (on observed proof) of the PPP. While, Taylor and Taylor (2004) assume that the debate in academic world about the PPP competence as an exchange rate standard is still open and animated.

In recent years, after the breakdown of Bretton Wood Agreements, the interest rate parity (IRP) model has revealed invalidate since we observe that higher interest rates implies capital inflows and currency appreciation as consequences. Isard (1995) discredits the uncovered interest rate parity (UIP) model and postulates that unexpected information plays a bigger role in predicting exchange rates fluctuations than interest rate differentials. This finding support the idea that unexpected information about economic developments, policies, or other relevant factors has the main impact on fluctuations in exchange rates. Furthermore, it is become recognized that only a small part of exchange rates fluctuations are explained by interest differentials. Li Wenhao (2004) postulates that, the credibility of the basic theories, the purchasing power parity (PPP) and the uncovered interest parity (UIP) is undermined since these two theories are based on many unrealistic assumptions. 
However, explaining future exchange rate value using the past value of exchange rate and building Auto-Regressive Integrated Moving Average (ARIMA) model suffer also from serious limitations since fundamental forces have important influence on the exchange rate.

The failure of the basic theories and the limited explanation power of the ARIMA series motivate the multivariate co-integration analysis. This latter issue has recently analyzed in economic literature on the exchange rate and aim to answer whether the exchange rate is driven by fundamentals and, to what degree it can be scheduled? Regrettably, no model yet fruitfully forecasts the changes in exchange rate.

The concern of this paper is to present a validate model able to explain and forecast the dollar/euro exchange rate. We try to explain first, the current value of the dollar/euro exchange rate by their past values in terms of linear relationships. This can be realized modeling the dollar/euro exchange rate series in the form of ARIMA model. We study also the volatility of the dollar/euro exchange rate. However, as proved by economic literature, macroeconomic variables impact the dollar/euro exchange rate, we develop therefore, an economic model to explain the current behavior of dollar/euro exchange rate and we put to test the impact of fundamental variables on this exchange rate.

This paper is prepared as follows: Literature reviews are offered in section two. In section three we present the movement of dollar/euro exchange rate through the period beginning of 1999 to the end of 2012 and we assess the validity of the basic theories of exchange rate. In section four we model the dollar/euro exchange rate as ARIMA model and we evaluate the volatility of this exchange rate. In section five we identify the economic factors affecting the dollar/euro exchange rate. Section six explains the co-integration analysis and exposes the results of tests. Finally conclusions are present in section seven.

\section{Literature Review}

Although the economic literature includes wide studies on exchange rates and many economists proposed different theories to explain their movements, no theory can enthusiastically and winningly elucidate the changes of the dollar/euro exchange rate. All in all, the economic literature can be grouped in two classes of advances, class of expectation advances and class of fundamental advances. The latter class who explains the dollar/euro exchange rate fluctuations in terms of macro-economic variables is by far the mainstream.

Among the first group, where economists explore the capacity of ARIMA series to predict future exchange rate level, Bellgard and Goldschmidt (1999) investigated (aud/dollar) exchange rate using half hourly data during 1996. They studied the trading performance and forecasting precision of some conventional techniques, including random walk, exponential smoothing, and ARMA models with recurrent neural network (RNN) models. They brought to a close that statistical forecasting precision measures do not impact directly on profitability and foreign exchange time series show nonlinear patterns that are better explained by neural network models.

Tyree and Long (1995) deviated from the latter path. They analyzed the case of the daily dollar/dem price variations from 1990 to 1994 and they discovered that the studied NNR models are less effective than the random walk model. They also found from a forecasting point of view, that what little structure is really present may well be too insignificant to be of any use although, price changes are not strictly random. They acknowledged, that it is expected that the optimal forecasting technique is the random walk.

However, Dunis and Huang (2001), estimated an ARMA $(4,4)$ model forecasting the dollar/euro exchange rate. Their estimation was not good enough as some elasticity were insignificant at the $95 \%$ confidence level.

For their part, to model the dollar/euro exchange rate series for the period starting 1994 to October 2007, Weisang and Awazu (2008) presented three ARIMA models with fundamental economic variables. They revealed that, the best model for the monthly series is a linear relationship between its past three values and the current and past three values of the difference of the log-levels of the share prices indices between the Euro zone and United States.

Among the second group, many economists considered various models to examine the fundamentals affecting the dollar/euro exchange rate. The mainly studied variables were the gross domestic product (GDP) and the interest rate differential.

Maccauley (1997) predicted that the dollar/euro price will reveal inflation outcomes, growth performance, and long-term developments in net foreign-asset positions on both sides of the Atlantic. In short term however, the relation between business cycles and associated cycles in monetary policy will figure particularly in the dollar/euro fluctuations. 
Alberola et al. (1999) estimated the dollar/euro exchange rate considering the ratio of non-traded/traded goods prices and net foreign assets as explanatory variables. However, Chinn and Alquist (2000) recognized the narrow monetary aggregate M1, GDP, short-term interest rates, consumer price index (CPI) and the ratio of non-traded/traded goods prices as key explanatory variables. While, Alquist and Chinn (2002) used Johansen and Stock-Watson procedures to project co-integrating relationships between the real exchange rate, productivity, and the real price of oil.

However, Clostermann and Schnatz (2000) applied co-integration approaches and construct a synthetic euro/dollar price from 1975 to 1998 . They identified the real euro/dollar exchange rate, the international real interest differentials, the real long term yield spread oil prices, government spending and the ratio of non-traded/traded goods prices as fundamentals factors affecting exchange rate.

Lorenzen and Thygessen (2000) constructed an econometric model using net foreign assets, R\&D spending, demographics and ratio of non-traded/traded goods prices. While, Duval (2001) identified consumption, multifactor productivity, real long term yield spread and the ratio of non-traded/traded goods prices.

Also, similarly, Telletech (2000) identified the productivity, the government spending, real long-term yield spread, M1 and industrial production, as explanatory variables for his model. He found that the difference in real interest rates and productivity, and (in some conditions) the relative fiscal attitude and the real price of oil, have a significant influence on the effective dollar/euro price.

The impact of the flow of funds to stock market on exchange rate is identified by Bailley and Millard (2000), Meredith (2001) and Brooks et al. (2001). They advanced, explaining the shock on the demand that capital inflow increases share prices, as consequences, consumption and investment increase. On the supply side however, potential output is increased as consequences of the raise in labor productivity caused by the increase in capital stock cause in turn by higher investment.

Finally, Moosa (2002) presumed that market participants do not cause events actively; they rather forecast events passively since he found that short-term and medium-term expectations primarily impact the exchange rates. $\mathrm{He}$ also found that rational expectations have a small impact on the real world. Inherited from Keynes idea, Moosa postulated that since speculation is impulsive, the exchange rate movement will become random, if speculation dominates the short-term expectations.

In this paper, we aim to present insights on the configuration of the dollar/euro exchange rate time series in order to construct an adequate model for exchange rate forecasting. We use therefore in first steep, past values of the dollar/euro exchange rate time series to predict current value (ARIMA model) and we evaluate the volatility of this series. In second steep, we provide an economic model and we estimate the impact of theoretically chosen variables.

\section{The Market Movement and the Failure of Basic Exchange Rate Theories}

For long time the exchange rate theories were dominated by two main equilibrium theories of exchange rate: The PPP theory and the UIP theory. But can these theories explain on empirical ground the dollar/euro exchange rate fluctuations?

\subsection{Purchasing Power Parity Theory (PPP)}

In 1918, Gustav Cassel presented the PPP theory. This theory states the long-run equilibrium between the exchange rates and the price levels. The PPP exchange rate is the rate that equates the two currencies by eliminating the differences in the price levels between countries. The main theory element is the non-existence of price arbitrage. In other terms, the same article of trade must have exactly the same price in two different markets. If the same article of trade does not have the same price in two different markets, arbitrage transactions would occur. Therefore, the goods will be transported from lower price market to higher price market. As results, the supply of the article of trade on the lower price market rises. While the inverse would happen in the higher price market, prices would rapidly be equalized.

Suppose $S_{t}$ to be the nominal exchange rate dollar /euro (in terms of dollar per euro) (Note 1) and $P_{t}$ the price level in t-country. The PPP relationship is:

$$
S_{t}=P_{S_{t}} / P_{\text {eurot }}
$$

Or more generally

$$
S_{t}=Q_{t} P_{S_{t}} / P_{\text {eurot }}
$$

Where, $Q_{t}$ is the dollar/euro real exchange rate. $Q_{t}$ is the purchasing power of a currency relative to another. It is 
based on the GDP deflator measurement of the price level in the domestic and foreign countries, which is arbitrarily set equal to 1 in a given base year. Therefore, the level of the $Q_{t}$ is arbitrarily set depending on which year is chosen as the base year for the GDP deflator of two countries. The changes of the $\mathrm{Q}_{t}$ are instead informative on the evolution over time of the relative price of a unit of GDP in the foreign country in terms of GDP units of the domestic country. The real dollar/euro exchange rate $\left(\mathrm{Q}_{\mathrm{t}}\right)$ is calculated in this study as nominal exchange rate multiplied by the European harmonized consumer price index (HCPI) and divided by the US consumer price index (CPI). $Q_{t}$ is supposed to be constant. Should $Q_{t}$ not be constant, then the PPP relation doesn't hold.

We note therefore that, the impacts of PPP in forecasting exchange rate on long term have been admitted by (Rogoff, 1996). But forecasting effects of PPP on short-term failed to be validate by many literatures (Rogoff, 1996; Lothian and Taylor, 1996; Grossman and Rogoff, 1995). In this study, to investigate if the PPP can be admitted for the dollar/euro exchange rate from the beginning of 1999 to the end of 2012, we compare between the real exchange rate $\left(Q_{t}\right)$ fluctuations and the inflation differential fluctuations.

All the monthly time series considered in this paper cover a period from beginning 1999 to the end of 2012 and are collected from OECD.Stat. The monthly fluctuations of the dollar/euro real exchange rate $\left(\mathrm{Q}_{t}\right)$ for the considered period are drawn in figure 1 . As we can see, the real exchange rate fluctuates considerably. More precisely, the real dollar/euro exchange rate starts at the value 1.19 and fluctuates between 1.6 and 0.8 . This means that the dollar/euro real exchange rate fluctuates within a band of 0.8 . This fluctuation band equates $70 \%$ of the value of the dollar/euro real exchange rate, indicating that the $\mathrm{Q}_{t}$ series fluctuates widely.

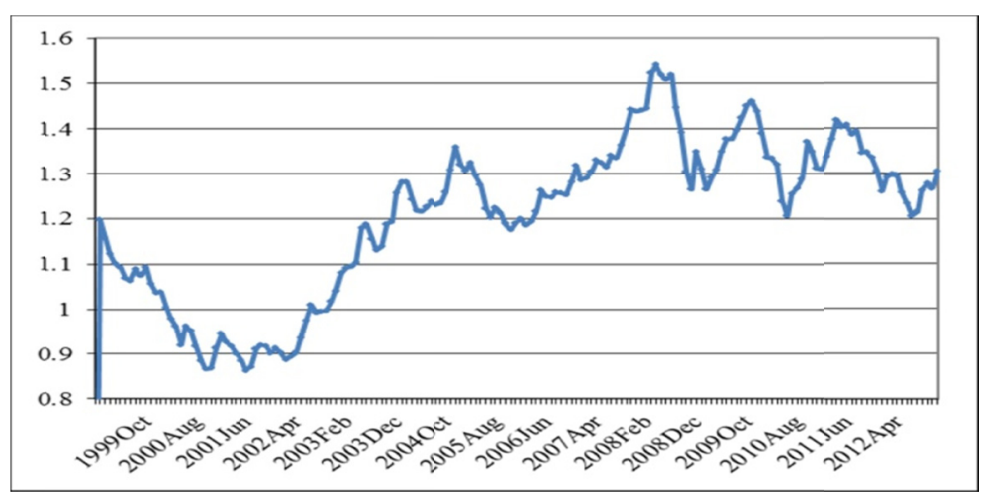

Figure 1. The monthly real euro/dollar exchange rate from 1999 to 2012

The monthly American consumer price index (CPI) and the Euro zone harmonized consumer price index (HCPI) series for 2005 as base year are drawn in figure 2. This figure shows that these two general prices level are close during the considered period. Furthermore, the figure 3 where the HCPI/CPI ratio is drawn shows that this ratio is around 1. More precisely, the ratio is between 0.96 and 1.03 for all the period proving that this ratio had small fluctuations.

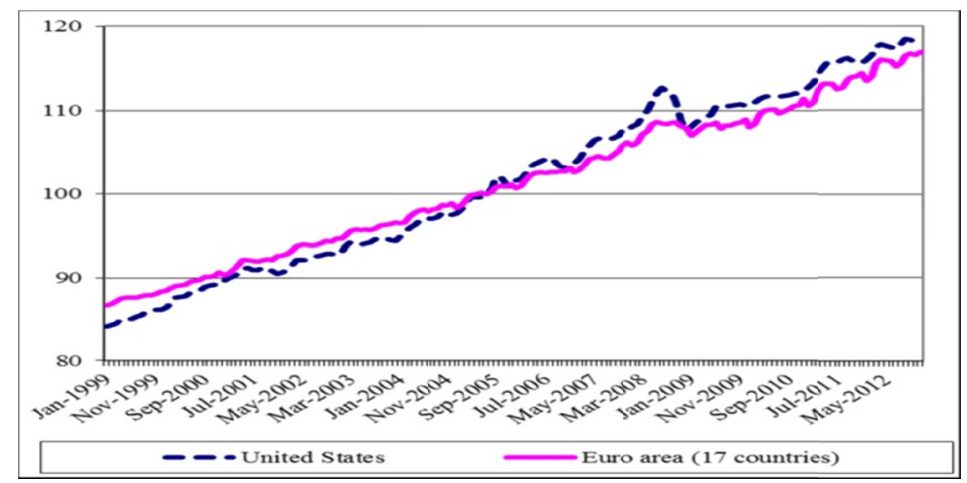

Figure 2. The monthly American CPI and European HCPI from1999 to 2012 


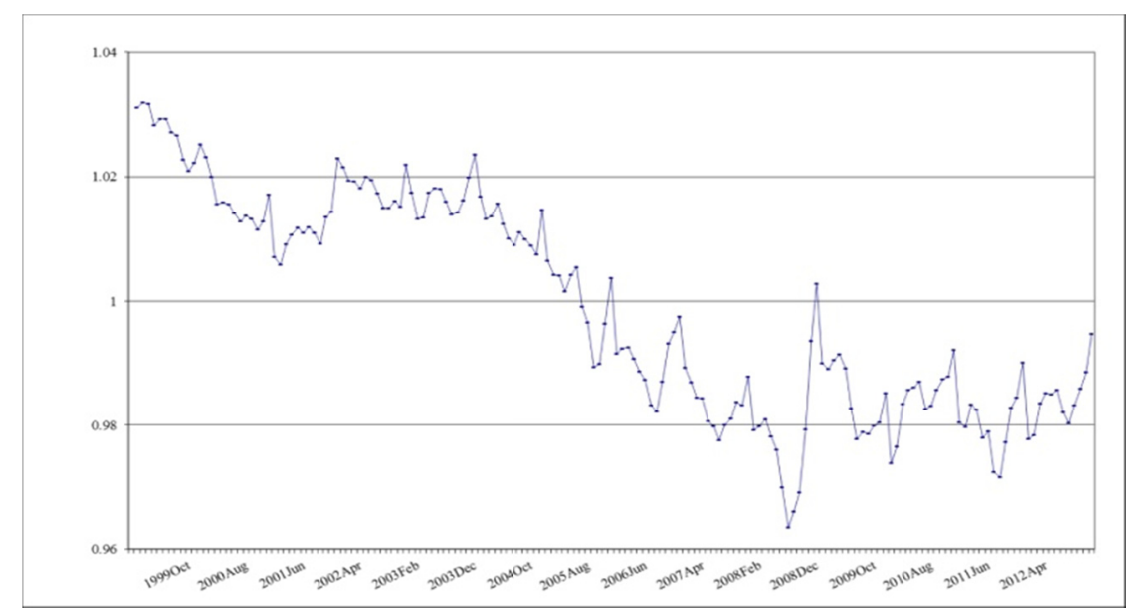

Figure 3. The monthly ratio HCPI/CPI from 1999 to 2012

Since $\mathrm{Q}_{\mathrm{t}}$ fluctuates largely while the HCPI/CPI ratio is close to 1 for the same period, we conclude that the PPP theory fail to explain the fluctuations of the dollar/euro exchange rate.

\subsection{Interest Rate Parity (IRP)}

IRP is a fundamental relationship that relates interest rates and exchange rates. It refers to a potential financial arbitrage if there is differential in interest rates between two currencies. If the differential interest rate is not null, an arbitrage opportunity will occur. Investors will have a loan in the currency with the lower interest rate and invest it in the currency with the higher interest rate. If this arbitrage persists, this would guide to infinite wealth. So there must be a means that balances the interest rates differential. This means is the exchange rate. The IRP is then a no arbitrage condition representing an equilibrium state under which investors will be indifferent to interest rates available on bank deposits in two countries.

Figure 4 draws the monthly real interest rate differential between US and Euro area (RID) and the real dollar/euro exchange rate $\left(\mathrm{Q}_{t}\right)$ from beginning 1999 to the end of 2012. RID is calculated as the difference between immediate interest rate in US divided by US CPI and immediate interest rate in Euro area divided by the harmonized CPI of Euro area. Data are collected from OECD.Stat. If the IRP holds, an increase in RID (which means an increase in US interest rate over European interest rate) implies since no arbitrage condition that the value of dollar against euro should depreciate, $Q_{t}$ increases as consequences. This is contradictory to our observation covering the period 1999 to 2012 and drawn in figure 4, since this figure shows that $\mathrm{Q}_{t}$ and RID fluctuations are not positively correlated.

Furthermore, as shown in table1, From beginning 1999 to December 2000 the RID increased by $43 \%$, but the $\mathrm{Q}_{\mathrm{t}}$ declined by $13 \%$;. During 2000 RID declined by $35 \%$ and the RER declined by $12 \%$ only while during 2001 the RID declined by $213 \%$ and the $\mathrm{Q}_{t}$ declined by 3\%. During 2008 the RID increased by $1290 \%$ and the $\mathrm{Q}_{t}$ declined by $6 \%$. All to all we can conclude that the IRP fails to explain the $\mathrm{Q}_{t}$ variation.

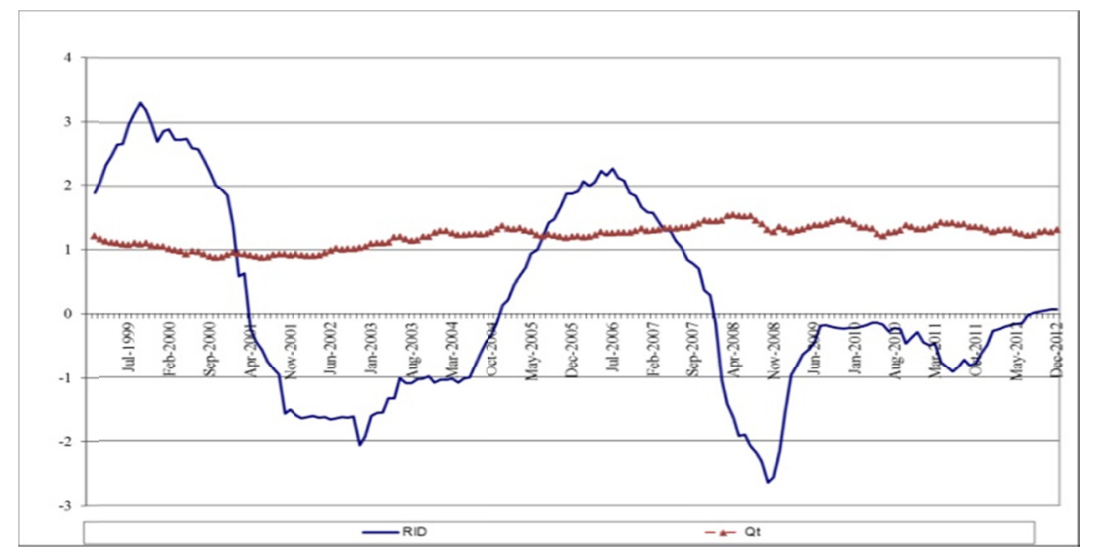

Figure 4. Monthly real interest rate differential and, the real dollar/euro exchange rate from 1999 to 2012 
Table 1. Annual variation of monthly real interest rate differential (d(RID)) and annual variation of monthly real dollar/euro exchange rate $\left(\mathrm{d}_{\left.\left(\mathrm{Q}_{\mathrm{t}}\right)\right)}\right)$ from 1999 to 2012

\begin{tabular}{|c|c|c|c|c|c|c|c|c|c|c|c|c|c|}
\hline years & 99 & 00 & 01 & 02 & 03 & 04 & 05 & 06 & 07 & 08 & 09 & 10 & 11 \\
\hline $\mathrm{d}(\mathrm{RID}) \%$ & 43.4 & -35.2 & -213.8 & 17.2 & -32.3 & -121.2 & 317.8 & -23.8 & -109.8 & 1294.2 & -86 & 30.9 & 9.5 \\
\hline $\mathrm{d}\left(\mathrm{Q}_{\mathrm{t}}\right) \%$ & -13.4 & -12 & -3.4 & 15.3 & 16.4 & 3 & -8.2 & 8.5 & 11.7 & -6.4 & 9.8 & -5.6 & -0.9 \\
\hline
\end{tabular}

Therefore, the unrealistic assumptions of the purchasing power parity and the interest rate theories undermine their credibility. In order to estimate the current dollar/euro real exchange rate we use in the next section the past value of this exchange rate.

\section{ARIMA Model and Volatility Estimation}

The methodology of Autoregressive Integrated Moving Average (ARIMA) estimation and model selection, also called Box-Jenkins (1984) models, is a classical topic covered in most textbooks on time series analysis (e.g. Brockwell \& Davis, 2003; Hamilton, 1994; Tsay, 2005; Wei, 2006).

We do not aim in this section to replicate the existing literature but rather to estimate the current value of dollar/euro exchange rate using its own past value as explanatory variables. The Autocorrelation Function (ACF) and Partial Autocorrelation Function (PCF) are used to estimate the ARIMA order by means of the regulations presented in Wei, 2005 p.109.

\subsection{Model Building}

The Correlogram of the real dollar/euro exchange rate $\left(\mathrm{Q}_{t}\right)$ series shows that only the ACF and the PACF of the first-differenced $Q_{t}$ series feature a decaying pattern with reasonable cut-off points. Conjointly, the guidelines of Wei regulations and the correlogram suggest an ARIMA $(2,1,0)$ structure. The evolution equation is then as follows:

This can be written:

$$
\left(1-\quad{ }_{1} B-{ }_{2} B^{2}\right)\left[\left(Q_{t^{-}} Q_{t t-1}\right)-\mu\right]=a_{t}
$$

$$
Q_{t}=\mu\left(\begin{array}{llll}
1- & 1 & 2
\end{array}\right)+\left(\begin{array}{lll}
1+ & 1
\end{array}\right) Q_{t-1}+\left(\begin{array}{ll}
2^{-} & 1
\end{array}\right) Q_{t-2}+{ }_{2} Q_{t-3}+a_{t}
$$

where $\mathrm{Q}_{t}$ represents the real dollar/euro exchange rate, $B$ is the backshift operator, and $a_{t}$ is random noise.

\subsection{Results}

\subsubsection{Stationary Results}

The dollar per euro real exchange rate series $\left(Q_{t}\right)$ presented in Fig 1 exhibits some non-stationarity. This non-stationarity is confirmed by the results of Augmented Dickey Fuller (ADF) test presented in table 2. These results prove that the $\mathrm{Q}_{t}$ series is not stationary in level but stationary in first difference. Therefore the $\mathrm{Q}_{t}$ series is integrated of order $1(\mathrm{I}(1))$.

Table 2. Results of ADF test for $\mathrm{Q}_{t}$ series by eviews

\begin{tabular}{ccccc}
\hline Variables & Lag & Calculated ADF in levels & Lag & Calculated ADF in Differences \\
\hline $\mathrm{Q}_{\mathrm{t}}$ & 1 & -1.470524 & 0 & $-9.4636671^{* * *}$ \\
\hline
\end{tabular}

Note: $* * *$, and $* * *$ show the statistical significance at the $10 \%, 5 \%$, and $1 \%$ level of significance respectively.

\subsubsection{Model Estimation}

The model estimation in least square method made by Eviews shows that the R-square is equivalent to (0.97) indicating an excellent fit for the model. The estimation results show also that Both $\mathrm{Q}_{\mathrm{t}-1}$ and $\mathrm{Q}_{\mathrm{t}-2}$ coefficients are significantly different from 0 with $\mathrm{p}$ values respectively $(0.0000)$ and $(0.0006)$. The constant and the $\mathrm{Q}_{\mathrm{t}-3}$ coefficient are not significantly different from 0 , since the p-value are $(0.1838)$ and $(0.1282)$ respectively (over $0.5 \%)$. The model estimation is as follows:

$$
\begin{aligned}
& \mathrm{Q}_{\mathrm{t}}^{*}=0.021648+1.2974 \mathrm{Q}_{\mathrm{t}-1}-0.434123 \mathrm{Q}_{\mathrm{t}-2}+0.119565 \mathrm{Q}_{\mathrm{t}-3} \\
& \begin{array}{llll}
(0.1838) & (0.0000) & (0.0006)+(0.1282)
\end{array}
\end{aligned}
$$


Equation (5) establishes the evolution of the dollar per Euro exchange rate as a weighted sum of its past three values plus a random shock where $\mathrm{Q}_{\mathrm{t}}{ }_{\mathrm{t}}$ is the estimation of $Q_{t}$ and the value in parentheses are the coefficient probabilities. We note the particularly small value of the constant in the latter evolution equation reflecting the short of significance of the estimate $\mu^{*}$. Furthermore, one interesting feature is, that because the time series of the exchange rate needs to be differenced once to be made stationary, the coefficients of this linear combination of past values sums to one. That is, the current value of the exchange rate can be interpreted as a weighted average of its three past values. Notice also that the coefficient of $t-1$ is greater in absolute value of $t-2$ and $t-3$, therefore giving proportionally more weight to the most recent values.

\subsection{Volatility Evaluation}

The analysis of the volatility of an exchange rate series is based on the returns of the data, which are the period by-period changes in the data. For example, returns on monthly exchange rate are the differences between exchange rates in two consecutive months. In this study the measure of the return is the difference in the exchange rate over two consecutive periods: $R_{t}=Q_{t}-Q_{t-1}$.

Generalized Autoregressive Conditional Heteroskedasticity (GARCH) (Note 2) formulation was used in this study to test whether the variance of returns is stationary and if price levels eventually revert back to a mean and, if they do, over what time period. The GARCH formulation tests an equation specification for the mean of the return series (6) and an equation for the conditional variance (7) of the returns:

$$
\begin{gathered}
R_{t}=Q_{t}-Q_{t-1}=c+\varepsilon_{t} \\
\sigma_{t}^{2}=\omega+\alpha \varepsilon_{t-1}^{2}+\beta \sigma_{t-1}^{2}
\end{gathered}
$$

where $\varepsilon_{t} \sim \mathrm{N}\left(0, \sigma_{\mathrm{t}}^{2}\right)$ and $\sigma^{2} \mathrm{t}=\mathrm{E}\left(\varepsilon_{t}^{2}\right)$.

This equation specification is often interpreted in a financial context, when an agent trader predicts this period's variance by forming a weighted average of a long term average (the constant), the forecasted variance from last period (the GARCH term: $\boldsymbol{\alpha}$ ), and information about volatility observed in the previous period (the ARCH term: $\boldsymbol{\beta})$. If the asset return was unexpectedly large in either the upward or the downward direction, than the trader will increase the estimate of the variance for the next period. Since the $Q_{t}$ series is integrated of order 1 , the Return series is stationary; we proceed then to measure the volatility.

\subsubsection{Volatility Measure}

The ARCH and GARCH test by Eviews gives the following estimation of equation 6:

$$
\begin{gathered}
\sigma_{t}^{2}=0.001574+0.073462 \varepsilon_{t-1}^{2}+0.80938 \sigma_{t-1}^{2} \\
(0.5) \quad(0.25) \quad(0.000)
\end{gathered}
$$

The values in parentheses are the coefficient probabilities. The sum of ARCH and GARCH $(\alpha+\beta)$ is very close to one, indicating that volatility shocks are quite persistent that is often observed in high frequency financial data. We proceed then to test if there is autocorrelation between the residuals.

\subsubsection{Autocorrelation in the Residuals Test Results}

The Lagrange multiplier (LM) tests for serial correlation by testing whether the serial correlation coefficients are significantly different from zero. The null hypothesis of the test is that there is no serial correlation in the residual up to the specified order. The LM test by Eviews indicates that we reject the hypothesis of no remaining significant autocorrelation in the residuals of the model up to order 2, since the Observed R-squared probability is 0.0041 (below $0.5 \%$ ). The presence of serial correlation suggests that the model do not seem to adequately capture the correlation information in the time series and the equation cannot be used for hypothesis test or forecasting.

ARIMA model fails to provide an explanation of the causal structure behind the evolution of the time series. Therefore, to get the structural relationships we specify the economic behavior of the dollar/euro exchange rate. In other terms we specify the long-term relationships between the dollar/euro exchange rate movement and the changes of fundamental variables.

\section{Fundamentals Affecting Exchange Rate}

In section 3, we found that the IRP and the PPP explain a part of the dollar/euro exchange rate variation but these two theories fail to explain all this variation. To model the dollar/euro exchange rate we consider then in addition to the impact of the IRP and the PPP explained in section 3, the impact of the Money Aggregates, and the Business Cycles. 


\subsection{Money Aggregates}

Since the breakdown of the Bretton Woods system of fixed exchange rates in early 1971s and the implementation of the floating exchange rate system, researchers have been motivated to explain the movements of exchange rates and have become interested in the monetary approach to exchange rate forecasting. In this approach, the relative price of two currencies is influenced by the supply and demand for money in two countries.

Money aggregates measure the stock of money in circulation within a country. We assume that the narrow money aggregate (M1) differential impacts the dollar/euro exchange rate. We consider in this study the narrow money index rate (MD) calculated as the US narrow money/European narrow money. When the MD increases, which means that the US monetary mass increases more than the European monetary mass, the dollar supply is higher than the euro supply. This implies that the euro value increases against the dollar value and the dollar per euro increases as consequences. In other term we assume a positive correlation between dollar/euro exchange rate and MD.

This assumption holds partially as we can see in Figure 5 where the monthly ratio of the Narrow Money (M1) Index 2005=100 in the United States and in the Euro area and, the nominal dollar/euro exchange are drawn. Figure 5 shows that in some period, more precisely, between 2003 and 2008 these two variables had an inverse movement.

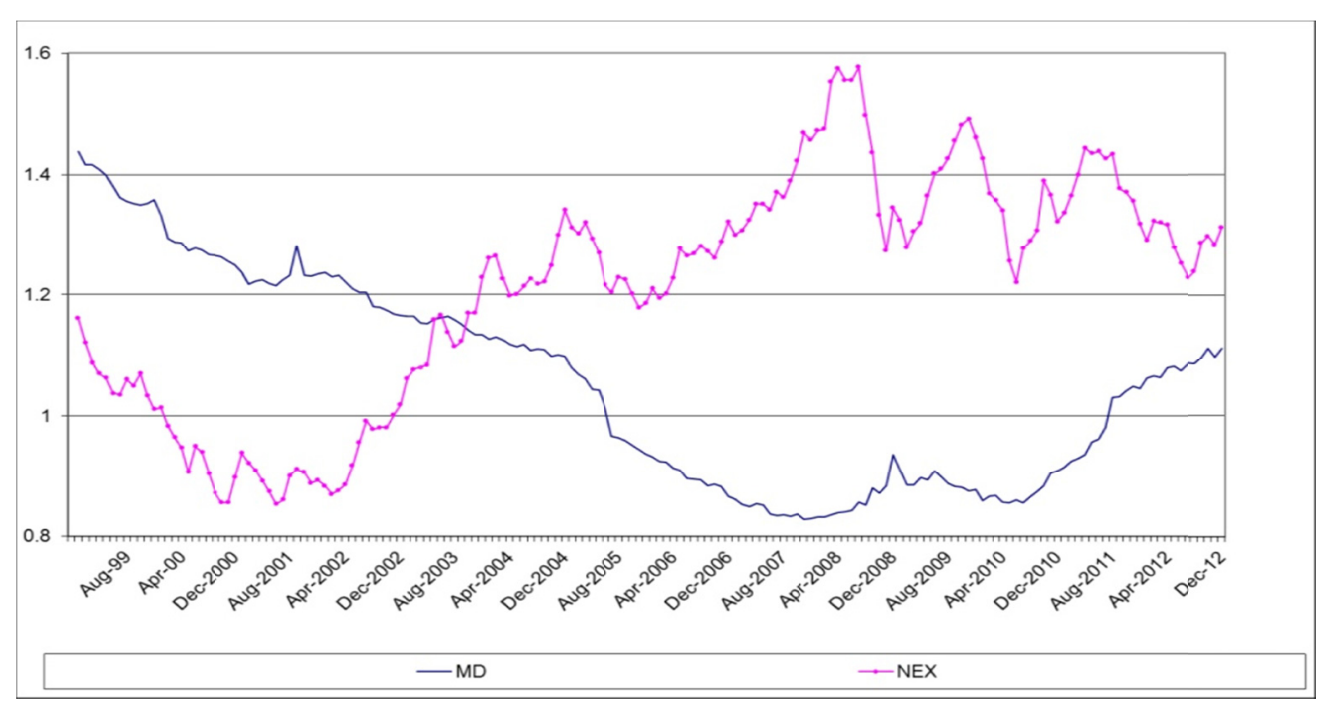

Figure 5. The monthly ratio (US M1/Euro area M1) and the dollar/euro real exchange rate from 1999 to 2012

\subsection{Business Cycles}

The term business cycle (or economic cycle) refers to economy-wide fluctuations in production, trade and economic activity in general over several months or years in an economy organized on free-enterprise principles. Business cycles have been considered in the literature as possibly influencing the movement of exchange rates. Since share prices track the business cycle quite closely, we include a measure of business cycles in our analysis by using the real share price indices. The share price indices are computed by the OECD. These indices are normalized such that their levels in $2005=100$. The share price ratio is the US nominal share price divided by the European share price indices.

The business cycle differential and the nominal dollar/euro exchange rate series are drawn in figure 6 . This figure shows that the two series are in inverse relation. In fact when the Share price indices in United the States is higher than the European one, this implies that the dollar demand is higher than the euro demand the dollar is then appreciate and the dollar/euro exchange rate decreases. 


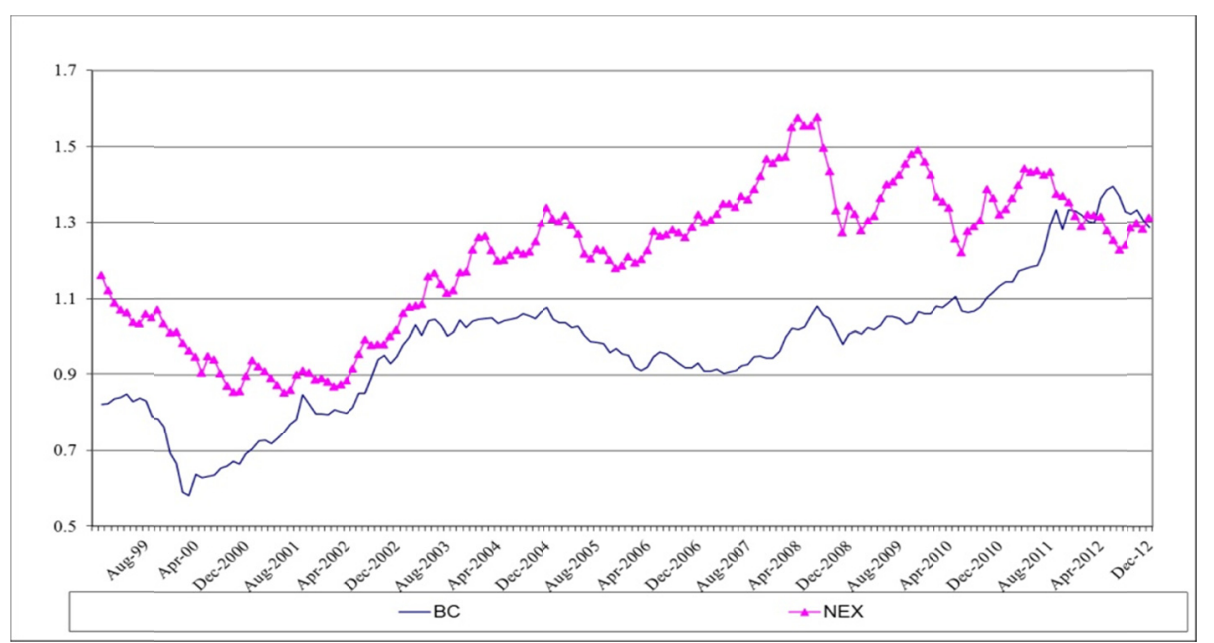

Figure 6. The monthly real share prices and the dollar/euro exchange rate from 1999 to 2012

\section{The Economic Model}

This section models the nominal dollar/euro exchange rate determination process with nominal dollar/euro exchange rate as dependent variable (NEX).

\subsection{Model Explanation}

We present in this section a model where the endogenous variable, the nominal value of dollar/euro exchange rate (NEX) is explained by four exogenous variables. In addition of the variables advanced by basic theories, the inflation differential (INF) and the interest rate differential (INT), we consider two other explanatory variables, the business cycles represented by the real share differential termed as (BC) and the money aggregates differential termed as (MD). The model is then as follows:

$$
N E X_{t}=b_{0}+b_{1} I N F_{t}+b_{2} I N T t_{t}+b_{3} B C_{t}+b_{4} M D_{t}+u_{t}
$$

In which $\mathrm{U}_{\mathrm{t}}=$ noise disturbance term at time $\mathrm{t}$, Monthly data from the first month of 1999 to the last month of 2012 are used for all variables.

The variable (INF) is measured as the Consumer Price Indices in Euro area (HCPI) divided by the Consumer price indices in the United State (CPI). The interest rate differential termed as (INT) is measured by the difference of real immediate interest rate between United States and Europe. The variable business cycles (BC) is represented by the real share in United State divided by the real share value in Europe. Finally, the money aggregate differential termed as (MD) is measured as the level of M1 in US divided by the level of M1 in Europe after normalizing in the same currency.

However, the regression coefficient associated with INF is expected to be negative-an increase in HCPI against CPI means an increase in European prices higher than the US prices. This implies according to the PPP, a decrease in the dollar per euro. We also expect that the coefficient of interest rate (INT) to be positive-an increase in US interest rate over the European interest rate will imply according to the IRP a decrease in the dollar value and an increase in the nominal dollar/euro exchange rate.

We expect thereby an inverse relationship between BC rate (US share prices/European share prices) and dollar/euro exchange rate. An increase in US share prices over the European share prices means an increase in the dollar demand. The dollar value will increase then over the euro value and the nominal dollar/euro exchange rate (NEX) declines.

Finally, we expect a direct relation between MD and NEX. An increase in the US monetary mass implies an increase in US prices and therefore a decrease in the dollar value against the euro according to PPP theory. This results in an increase in the nominal dollar/euro exchange rate (NEX).

\subsection{Econometric Methodology}

The concept of co integration, first introduced into the literature by Granger (1981), is relevant to the problem of the determination of long-run or 'equilibrium' relationships in economics. From a statistical point of view, a long-term relationship means that the variables move together over time so that short term disturbances from the 
long-term trend will be corrected. The purpose of the co-integration test is to determine whether a group of non-stationary series is co-integrated or not.

If the similarly integrated series in any given model are co integrated, then linear combinations of these variables will converge to stationary long-run equilibrium relationships. Thus, the non-stationary property of the series must be considered first. Testing for co integration is a second stage of pre-testing. The presence of a co-integrating relation forms the basis of the VEC specification. Only when this stage has been passed should we move on to the model building. To test for cointegration we use the method developed by Johansen (1991; 1995a). This method allows knowing the number of cointegrating vectors; it allows also using the vector error correction model (VEC) to estimate the equation (9). The VEC (Note 3) has co integration relations built into the specification so that it restricts the long-run behavior or the endogenous variables to converge to their co integrating relationships while allowing for short-run adjustment dynamic. The co integration term is known as the error correction term since the deviation from long-run equation is corrected gradually through a series of partial short-run adjustment.

\subsection{Results and Discussion}

\subsubsection{Stationary Test}

The stationary test results according to Augmented Dickey Fuller (ADF) test are reported in table 3. These results indicate that all series are not stationary in their level but stationary in their first difference. All series are then integrated of order one I(1).

Table 3. Results of ADF tests

\begin{tabular}{rrccc}
\hline Variables & Lag & Calculated ADF in levels & Lag & Calculated ADF in Differences \\
\hline INFt & 3 & -1.40089 & 2 & $-4.258050^{* * *}$ \\
INTt & 3 & -2.83528 & 2 & $-3.920852^{* * *}$ \\
RBCt & 0 & -0.256842 & 0 & $-10.67809^{* * *}$ \\
RMDt & 3 & -2.8406452 & 2 & $-3.778463^{* * *}$ \\
NEXt & 1 & -1.429218 & 0 & $-9.404308^{* * *}$ \\
\hline
\end{tabular}

Note: $* * *$, and $* * *$ show the statistical significance at the $10 \%, 5 \%$, and $1 \%$ level of significance respectively.

\subsubsection{Co-Integration Test}

Since All variables being I(1), we proceed to test for co integration. We estimate a multivariate co integration relationship to establish the existence of a long-run equilibrium relationship. The Johansen's Maximum Likelihood co integration test relations were estimated with intercept and linear deterministic trend in a Vector Auto Regression (VAR) model of order 1 with a lag length of 4, which was found to be the most parsimonious for the data series. The Johansen co integration tests are based on the Maximum Eigenvalue of the stochastic matrix as well as the Likelihood ratio test which is in turn based on the Trace of the stochastic matrix. Table 4 below shows the summary results of the Johansen's Maximum Likelihood co integration test. For the null hypothesis of $\mathrm{r}=0$, the calculated trace statistics was larger than its critical value and calculated maximum Eigenvalue was also larger than its critical value at 5\% level of significance. From the results, it is evident that both the trace test and the maximum Eigenvalue test indicate one co-integrating equation as the null hypothesis of $r=0$ is rejected. Thus, it may be concluded that there is a unique long-run equilibrium relationship between the variables. 
Table 4. Results of cointegration tests

\begin{tabular}{ccccc}
\hline Null Hypothesis & Alternative Hypothesis & & 0.05 Critical Value & Probability \\
\hline & & $\lambda_{\text {trace }}$ value & \\
$\mathrm{r}=0$ & 68.18658 & 60.06141 & 0.0088 \\
$\mathrm{r}<=1$ & $\mathrm{r}=0$ & 35.00855 & 40.17493 & 0.1504 \\
$\mathrm{r}<=2$ & $\mathrm{r}>1$ & 24.27596 & 0.6033 \\
$\mathrm{r}<=3$ & $\mathrm{r}>2$ & 2.475198 & 12.32090 & 0.9078 \\
$\mathrm{r}<=4$ & $\mathrm{r}>3$ & 0.935569 & 4.129906 & 0.3861 \\
& $\mathrm{r}>4$ & $\lambda_{\text {max }}$ tests & & \\
$\mathrm{r}=0$ & 33.17803 & 30.43961 & 0.0222 \\
$\mathrm{r}=1$ & $\mathrm{r}=1$ & 21.79295 & 24.15921 & 0.1013 \\
$\mathrm{r}=2$ & $\mathrm{r}=2$ & 10.74040 & 17.79730 & 0.4103 \\
$\mathrm{r}=3$ & $\mathrm{r}=3$ & 1.539629 & 11.22480 & 0.9650 \\
$\mathrm{r}=4$ & $\mathrm{r}=4$ & 0.935569 & 4.129906 & 0.3861 \\
\hline
\end{tabular}

Notes: Trace and max-eigenvalue tests indicate 1 cointegrating equation at the 0.01 level of significance. $r$ indicates the number of cointegrating vector and $\lambda_{\text {trace }}$ and $\lambda_{\text {max }}$ are tests statistic of trace and maximum eigenvalue tests respectively.

\subsubsection{Vector Error Correction Model}

These results imply that a long-run association exists among the exchange rate and the four explanatory variables. Then, the long-run estimated coefficients are reported in Table 5.

Table 5. Estimated long-run model

\begin{tabular}{ccl}
\hline & Dependent Variable $N E X_{t}$ \\
Variable & Coefficient & $t$-value \\
\hline$I N F_{t}$ & -1.81816 & $-6.5947^{* * *}$ \\
$I N T_{t}$ & 0.061471 & $3.41834^{* * *}$ \\
$M D_{t}$ & 0.98423 & $6.12700^{* * *}$ \\
$B C_{t}$ & -0.45525 & $2.62977^{* *}$ \\
\hline
\end{tabular}

Note: *,**, and $* * *$ indicate the rejection of the null hypothesis at the $10 \%, 5 \%$, and $1 \%$ level of significance respectively.

In the long run, all the model variables are statistically significant with the expected sign coefficient. We note however the high elasticity of inflation, in fact the model estimation shows that in the long run the variable INF has the more influence on the nominal exchange rate (elasticity -1.8 ), follows by MD (elasticity 0.9 ) and $\mathrm{BC}$ (elasticity -0.45) and INT(0.06).

It may be observed also from the VEC estimation by Eviews that the model fits the observed data fairly and significance of estimated relationships as indicated by the adjusted $\mathrm{R}^{2}(0.268534)$ and F-statistic $(3.546295)$ of the relevant error correction equation. The error correction coefficient $(-0.068599)$, which measures the speed of adjustment towards long-run equilibrium carries the expected negative sign and it is highly significant at the $1 \%$ level. It shows however that about $6 \%$ of disequilibrium is "corrected" each month by changes in nominal exchange rate (NEX). The estimation of short term model is reported in Table 6. 
Table 6. Estimated short-run model

\begin{tabular}{ccc}
\hline \multicolumn{2}{l}{ Dependent Variable $\mathrm{D}\left(N E X_{t}\right)$} & \\
\hline Variable & Coefficient & $t$-value \\
\hline Error term (-1) & -0.068599 & -3.41652 \\
$\mathrm{D}(\mathrm{NEX}(-1))$ & 0.431022 & 5.12447 \\
$\mathrm{D}(\mathrm{NEX}(-2))$ & -0.074496 & -0.79887 \\
$\mathrm{D}(\mathrm{NEX}(-3))$ & 0.027987 & 0.30457 \\
$\mathrm{D}(\mathrm{NEX}(-4))$ & 0.045570 & 0.50502 \\
$\mathrm{D}(\mathrm{INF}(-1))$ & 0.667215 & 1.03257 \\
$\mathrm{D}(\mathrm{INF}(-2))$ & $-0.769573)$ & -1.26778 \\
$\mathrm{D}(\mathrm{INF}(-3))$ & -0.133639 & -0.22241 \\
$\mathrm{D}(\mathrm{INF}(-4))$ & $0.434727)$ & 0.70418 \\
$\mathrm{D}(\mathrm{INT}(-1))$ & 0.000229 & 0.01565 \\
$\mathrm{D}(\mathrm{INT}(-2))$ & -0.023216 & -1.60169 \\
$\mathrm{D}(\mathrm{INT}(-3))$ & 0.012478 & 0.87264 \\
$\mathrm{D}(\mathrm{INT}(-4))$ & 0.008754 & 0.61998 \\
$\mathrm{D}(\mathrm{MD}(-1))$ & -0.237811 & -1.19892 \\
$\mathrm{D}(\mathrm{MD}(-2))$ & -0.227535 & -1.15426 \\
$\mathrm{D}(\mathrm{MD}(-3))$ & 0.012894 & 0.06388 \\
$\mathrm{D}(\mathrm{MD}(-4))$ & 0.049600 & 0.24161 \\
$\mathrm{D}(\mathrm{BC}(-1))$ & -0.262492 & -2.27498 \\
$\mathrm{D}(\mathrm{BC}(-2))$ & 0.039305 & 0.33335 \\
$\mathrm{D}(\mathrm{BC}(-3))$ & 0.025797 & 0.21344 \\
$\mathrm{D}(\mathrm{BC}(-4))$ & -0.242977 & -2.05202 \\
\hline & & \\
& & \\
\hline
\end{tabular}

The short run equilibrium estimation shows that the variable NEX in time t-1 is statistically significant and affects the NEX in time t. It shows also that the variable BC in time t- 1 and in time t- 4 is statistically significant and affects the NEX in time t. The other variables at different time are not statically significant; we note therefore the low elasticity of all exogenous variables.

\section{Conclusion}

In one hand, the basic theories, the Power purchasing parity and the Interest rate parity explain partially the dollar/euro exchange rate. In other hand, we have seen above that a simple ARIMA model can provide an evolution equation with a simple interpretation. Although the exchange rate series presents a high volatility, the presence of serial correlation suggests that the model do not seem to adequately capture the correlation information in the time series and the model cannot be used for hypothesis test or forecasting. Furthermore, ARIMA model can be criticized because it fails to provide an explanation of the causal structure behind the evolution of the time series.

Therefore, the model developed in this study consider in addition to the two variables proposed by basic theories, two other variables, one variable representing the Money Aggregates, and one variable representing the Business Cycles. 
According to our model estimation, the most important variable affecting the dollar/euro exchange rate is inflation differential between Europe and US. In other terms, the PPP theory explain the main part of the dollar/euro exchange rate followed by the monetary aggregate differential while as it is found by a wide literature, the interest differentials explain only a small proportion of subsequent changes in exchange rates. These mean that the inflation differential is the most important variable to forecast the nominal dollar/euro exchange rate.

\section{References}

Alberola, E., Susanna, G., Cervero, H. L., \& Angel, U. (1999). Global equilibrium exchange rates: Euro, Dollar, "Ins", "Outs", and other major currencies in a panel cointegration framework. IMF Working Paper No. 99/175, Washington, DC.

Alquist, R., \& Chinn, M. D. (2002). Productivity and the Euro-dollar exchange rate puzzle. Cambridge: National Bureau of Economic Research.

Bailley, A., \& Millard, S. (2000). Capital flows and exchange rates. Bank of England Quarterly Bulletin, Autumn, 310-318.

Bellgard, C., \& Goldschmidt, P. (1999). Forecasting across frequencies: Linearity and non-linearity. University of Western Australia Research Paper, Proceedings of the International Conference on Advanced Technology, Australia

Brent, S. (2006). Is reversion to PPP in Euro exchange rate non-Linear? European Central Bank, working paper series no 682/ October.

Brockwell, P. J., \& Davis, R. A. (2003). Introduction to time series and forecasting. New York, NY.: Springer.

Brooks, R. et al. ( 2001). Exchange rates and capital flows. IMF working Paper. WP/01/190.

Chinn, M., \& Alquist, R. (2000). Tracking the Euro's progress. International Finance, 3(3), 357-73. http://dx.doi.org/10.1111/1468-2362.00056

Clostermann, J., \& Schnatz, B. (2000). The determinants of the Euro-Dollar exchange rate: Synthetic fundamentals and a non-existing currency. Deutsche Bundesbank Discussion Paper no.2/00.

Dickey, D. A., \& Fuller, W. A. (1981). Likelihood ratio statistics for autoregressive time-series with a unit root. Economica, 49, 1057-1072. http://dx.doi.org/10.2307/1912517

Dunis, C., \& Huang, X. (2002). Forecasting and trading currency volatility: An application of recurrent neural regression and model combination. Liverpool Business School Working Paper

Duval, R. (2001). Estimation du taux de Change réel d'équilibre de long terme dollar/euro par une approche dynamique synthétique. Photocopy.

Enders, W. (2004). Applied Econometric Time Series (2nd ed.). Alabama: Wiley Series in Probability and Statistics.

Engle, R. F., \& Granger, C. W. J. (1987). Co-integration and error correction: Representation, estimation and testing. Econometrica, 55(2), 251-276. http://dx.doi.org/10.2307/1913236

Granger, C. W. J. (1969). Investigating causal relations by econometric models and cross-spectral methods. Econometrica, 37, 424-438. http://dx.doi.org/10.2307/1912791

Granger, C. W. J. (1981). Some properties of time series data and their use in econometric model specification. Journal of Econometrics, 16, 121-130. http://dx.doi.org/10.1016/0304-4076(81)90079-8

Grossman, G., \& Rogoff, K. (1995). Handbook of international economics (Vol. 3). Amsterdam: North-Holland.

Hamilton, J. D. (1994). Time series analysis. Princeton, NJ: Princeton University Press.

Isard Peter. (1995). Exchange rate economics. Cambridge University press.

Johansen, S., \& Juselius, K. (1988). Hypothesis testing for co-integration vectors: With application to the demand for money in Denmark and Finland. University of Copenhagen. Department of Economics in its series Discussion Papers with number 88-05.

Li, W. (2004). Currency competition between Euro and US dollar. Working paper no 18 of the Business Institute Berlin at Berlin School of Economics.

Lorenzen, H., \& Thygessen, N. (2000). The relation between the Euro and Dollar. Paper presented at the EPRU conference on Perspectives on Danish and European Economic Policy, Copenhagen, November 9-10. 
Lothian, J., \& Taylor, M. (1996). Real exchange rate behavior: The recent float from the perspective of the past two centuries. Journal of Political Economy, June, 488-509. http://dx.doi.org/10.1086/262031

Maccauley, R. N. (1997). The Euro and the Dollar. Essays in International Finance, No. 205, November.

Meese, R., \& Rogoff, K. (1983). Empirical exchange rate models of the seventies: Do they fit out of sample? Journal of International Economics, 14, 3-24. http://dx.doi.org/10.1016/0022-1996(83)90017-X

Meredith, G. (2001). Why has Euro been so weak? IMF Working Paper, WP/01/155.

Michael, R. R. (2003). The dollar's equilibrium exchange rate: a market view. Institute for international economics.

Moosa, I. A. (2002). A test of the post Keynesian hypothesis on expectation formation in the foreign exchange marke. Journal of Post Keynesian Economics, 24(3), 443-457.

Rogoff, K. (1996). The purchasing power parity puzzle. Journal of Economic Literature, 34, 2, 647-668.

Sartore, D., Trevisan, L., Trova, M., \& Volo, F. (2001). US Dollar/Euro exchange rate: A monthly econometric model for forecasting. GRETA working paper n.01.04, Luglio.

Taylor, M., Peel, D. A., \& Sarno, L. (2001). Non-linear mean-reversion in real exchange rates: Towards a solution to the purchasing power parity puzzles. International Economic Review, 42(4), 1015-1042. http://dx.doi.org/10.1111/1468-2354.00144

Teiletche, J. (2000). La parité dollar/euro Durant les décennies 80 et 90: Peut-on trouver une spécification raisonnable et a quel horizon?. Photocopy (Décembre).

Tsay, R. S. (2005). Analysis of financial time series. New York, NY.: Wiley. http://dx.doi.org/10.1002/0471746193

Tyree, E. W., \& Long, J. A. (1995). Forecasting currency exchange rates: Neural networks and the random walk model. City University Working Paper, Proceedings of the Third International Conference on Artificial Intelligence Applications, New York. Retrieved from http://citeseer.nj.nec.com/131893.html

Wei, W. W. S. (2005). Time series analysis: Univariate and multivariate methods (2nd ed.). New York, NY: Addison Wesley.

Weisang, G., \& Yukika, A. (2008). Vagaries of the Euro: An Introduction to ARIMA modeling. Retrieved from http://legacy.bentley.edu/csbigs/documents/weisang.pdf

\section{Notes}

Note 1. An increase in exchange rate means an appreciation of euro against US dollar.

Note 2. GARCH model is consistent with the volatility clustering often seen in financial returns data, when large changes in return is likely to be followed by further large changes.

Note 3. A VEC model is a restricted VAR designed for use with non-stationary series that are known to be cointegrated.

\section{Copyrights}

Copyright for this article is retained by the author(s), with first publication rights granted to the journal.

This is an open-access article distributed under the terms and conditions of the Creative Commons Attribution license (http://creativecommons.org/licenses/by/3.0/). 